\title{
Open Reduction of the Isolated Anterior Frontal Sinus Fracture
}

Bonny Murizky¹, Al Hafiz²

\begin{abstract}
The anterior wall of the frontal sinus is extremely resilient to injury. Incidents involving high-velocity impact, such as motor vehicle accidents, gunshots and sports injuries, may result in frontal sinus fractures. Clinical symptoms are associated with location and the severity. The best way to diagnose with a combination of clinical examination and CT scan. The management is mostly based on open reduction and internal fixation. The objectives was the importance of doing right management in patients with frontal sinus fracture. Reported a case of maxillofacial multiple fractures (right frontal fracture + right maxilla fracture) in a 28-year-old man, performed open reduction and internal fixation. Frontal sinus fracture is a fracture generally occurs due to traffic accidents. Anamnese of patient complaints and symptoms, physical examination and 3D CT scan can help make the diagnosis, and surgeons should give attention to the management criteria to prevent complication.
\end{abstract}

Keywords: frontal sinus fracture, delayed management, CT scan

\begin{abstract}
Abstrak
Dinding anterior sinus frontal termasuk kuat terhadap cedera. Insiden yang melibatkan benturan kecepatan tinggi, seperti kecelakaan kendaraan bermotor, tembakan dan cedera olahraga, dapat menyebabkan fraktur sinus frontal. Gejala klinis berhubungan dengan lokasi dan tingkat keparahan. Cara terbaik untuk mendiagnosis dengan kombinasi pemeriksaan klinis dan CT scan. Manajemen sebagian besar didasarkan pada reduksi terbuka dan fiksasi internal. Tujuan studi ini adalah melakukan penatalaksanaan yang tepat pada pasien dengan fraktur sinus frontal. Kasus: Dilaporkan suatu kasus fraktur multipel maksilofasial (fraktur sinus frontal kanan+fraktur maksila kanan) pada pria berusia 28 tahun, dilakukan reduksi terbuka dan fiksasi internal. Fraktur sinus frontal merupakan fraktur yang umumnya fraktur ini terjadi akibat kecelakaan lalu lintas. Anamnesis mengenai keluhan dan gejala yang dirasakan pasien, ditambah pemeriksaan fisik serta pemeriksaan CT scan 3D dapat membantu menegakkan diagnosis, ahli bedah harus memperhatikan kriteria penatalaksanaan untuk mencegah terjadinya komplikasi
\end{abstract}

Keywords: fraktur sinus frontal, delayed management, CT scan

Affiliasi penulis : 1. Program Penddikan Dokter Spesialis THT-KL, Fakultas Kedokteran, Universitas Andalas, Padang, Indonesia. 2. Bagian THT-KL, Fakultas Kedokteran, Universitas Andalas, Padang, Indonesia.

Korespondensi : Al Hafiz [hafizdjosan.ent@gmail.com] Telp: $+6281315467915$

\section{INTRODUCTION}

The anterior wall of the frontal sinus is extremely resilient to injury. Incidents involving highvelocity impact, such as motor vehicle accidents, gunshots and sports injuries, may result in frontal sinus (FS) fractures. The anatomy and surgical treatments for FS fractures are distinct; however, the surgical proximity of these two areas warrants a combined discussion. Patients with FS and NOE complex fractures often have multiple associated injuries. ${ }^{1}$ Frontal sinus fractures frequently coincide with orbital fractures and midface fractures. The involvement of the facial skeleton in frontal sinus fractures increases depending on the severity of the traumatic impact. In $53 \%$ of the anterior frontal sinus wall fractures (type I), additional fractures of the 
midface are found (12\% of them have classic midface fractures). In fractures of the posterior frontal sinus wall (type II or type III), 95\% additional fractures of the midface are found $(25 \%$, respectively $23 \%$ of them have classic midface fractures. ${ }^{2}$

The etiologies of maxillofacial fractures vary from one geographical location to another and also among different age groups. Road Traffic Accident (RTA) has been severally reported as the leading etiology of maxillofacial fractures especially in the developing world. Young men in the second and third decades of life are the worst afflicted owing to the fact that they engage frequently in activities that can predispose them to trauma. ${ }^{3}$ Neid hardt ${ }^{2}$ in his study in 2002 , $62 \%$ of the patients were between 16 and 45 years old when the accident occurred. The group of 16-30 years was the largest, with $38 \%$ of all craniofacial fractures. Comprising $24 \%$, the group of 31-45 years was the next largest, followed by the group of $46-60$ years with $17 \%$. Also significant were the $10 \%$ that were children between 1 and 15 years of age and the $11 \%$ of patients between 60 and 90 years. ${ }^{2}$ Apart from RTA and assaults, other common causes of maxillofacial fractures include sporting injuries, industrial accidents, domestic accidents, falls, and animal bites. The age-long principle of fracture management; reduction and immobilization also applies to maxillofacial fractures; however, the pathway to achieving this principle is influenced by many other factors. It should be noted that the treatment outcome of maxillofacial fractures is mainly dependent among other things on the degree of injury, type of fracture, the expertise of the surgeon, and available technology. ${ }^{3}$ Computed tomography (CT) has become the imaging standard of reference in evaluating these injuries to determine which patients will require surgical intervention for their bony injuries. The surgical treatment of displaced craniofacial fractures centers around restoring the preinjury alignment of the skeleton by using rigid fixation. To achieve this goal, the facial skeleton can be conceptualized as a series of buttresses that serve to support both the form and function of the face. ${ }^{4}$

The initial evaluation should be focused on airway maintenance and hemodynamic stability. After the patient is stabilized, the brain, spine, orbits, and facial skeleton should be evaluated. ${ }^{1}$ Acute concerns include protection of intracranial structures, identification of associated injuries and control of cerebrospinal fluid (CSF) leakage. The aesthetic forehead contour is also an important consideration in repair. Past surgical modalities that removed the anterior bony frontal surface left life-long disfiguring defects and have been largely replaced by techniques that leave a smooth contour without visible scars. ${ }^{5}$

\section{ANATOMY}

The FS is absent at birth. At 2 years of age, the anterior ethmoid cells invade the frontal bone to form a rudimentary cavity. By 6 years of age, the FS can be detected radiographically. At 15 years of age, the FS is adult-sized. The FS is pyramidal in shape with the base located inferiorly and the apex superiorly. ${ }^{1}$

Dimension and form of the frontal sinuses vary greatly. The average dimensions are as follows : height $30 \mathrm{~mm}$, width $25 \mathrm{~mm}$, depth $19 \mathrm{~mm}$, and volume $10 \mathrm{~cm}^{3}$. The anterior table thickness may be as great as $12 \mathrm{~mm}$ (average $4 \mathrm{~mm}$ ), whereas the posterior table ranges in thickness from 0.1 to 4.8 $\mathrm{mm} .{ }^{1}$ They may be totally absent (aplasia) or extend asymmetrically into the orbital roof depending on the degree of pneumatization, may be completely absent $(5 \%)$ and is usually divided by an intersinus septum.1,6 In the latter case, they may even reach the anterior margin of the lesser wing of the sphenoid bone. Laterally, the frontal sinus can extend as far as the zygomatic process of the frontal bone and occasionally comprise the lateral orbital wall. ${ }^{2}$

The posterior table forms a portion of the anterior cranial fossa. ${ }^{1,2}$ The anterior table of the frontal sinus is twice as thick as the posterior table forms part of the forehead, brow, and glabella. ${ }^{1,6}$ The floor of the sinus also functions as the supraorbital roof, and the drainage pathway is located in the posteromedial portion of the sinus floor. ${ }^{1}$

The frontonasal duct is the most anterior and superior portion of the anterior ethmoid complex and drains the frontal sinus into the middle meatus. The term frontal recess is also used instead of frontonasal duct, because an anatomical duct from the frontal 
sinus is not present. ${ }^{6}$ The Nasofrontal Recess (NFR) is the sole drainage site for the FS. Each ostium is approximately $3 \times 4 \mathrm{~mm}$ in diameter and located on the posterior inferior aspect of the sinus floor. The ostium lies anterior to the anterior ethmoid air cells, medial to the orbit, lateral to the intersinus septum, and posterior to the frontal bone. NFR is the sole drainage site for the FS. ${ }^{1}$ Like the frontal sinus itself, the frontonasal duct displays significant anatomical variations. However, in most individuals, the superior portion of the uncinate process forms the anterior border of the duct. ${ }^{10}$

Drainage of the FS is complex with its outflow tract resembling an hourglass shaped structure in the sagittal plane. The most common variation, the anterosuperior portion of the uncinated process inserts onto the lamina papyracea so that the uncinate process separates the ethmoidal infundibulum from• the frontal recess. In this setting, the frontal recess opens into the middle meatus medial to the ethmoidal infundibulum, between the uncinate process and the middle turbinate. When the uncinate process inserts onto the ethmoid roof or inserts onto the middle turbinate, the frontal recess opens directly into the ethmoidal infundibulum, and is thought to be subject to obstruction in the presence of ethmoid inflammation. ${ }^{6}$ During endoscopic sinus surgery, the opening of the frontal sinus is often more medial than anticipated. The frontal sinus opens into the middle meatus medial to• the uncinate process in $88 \%$ of patients and lateral to the uncinate in the remaining $12 \%$ of patients. ${ }^{6}$

\section{Frontal sinus fracture}

The FS is protected by thick cortical bone and is more resistant to fracture than any other facial bone. ${ }^{1}$ FS fractures account for only 5 to $15 \%$ of maxillofacial injuries and are most commonly• associated with motor vehicle accidents, sporting events, and assaults. ${ }^{1}$ With the advent of airbags, however, they are much less frequent. Severe aggravated assaults are much more commonly seen now as the underlying cause, as are motor vehiclepedestrian accidents. Because of the significant underlying forces involved, many of these patients will have also sustained intracranial injuries, requiring a multidisciplinary approach to the patient's overall management. ${ }^{7}$ The extreme force required to fracture the anterior table of the FS results in serious associated injuries in $75 \%$ of patients. Sixty-six percent of patients have associated facial fractures. Mortality rates as high as $25 \%$ have been reported with severe through-and-through injuries. Isolated anterior table fractures occur in approximately $33 \%$ of these injuries. Combined fractures of the anterior table, posterior table, or the NFR account for approximately $67 \%$ of frontal sinus injuries. Isolated posterior table injuries uncommon. ${ }^{1}$

These fractures are staged according to the extent and dimension of the fracture and subdivided into the following fracture types ${ }^{1}$ :

- Isolated frontal sinus fractures

- $\quad$ Fractures of frontal sinus and ethmoid

Fractures of frontal sinus, orbit, ethmoid, and bridge of the nose

Godbersen and Kugelgen in their study at 1998 said the varying fracture types can be differentiated with regard to their pathogenesis and surgical therapy:

Classification of frontal sinus fractures (Godbersen and Kügelgen 1998)²

Type 1;

Frontal sinus - anterior wall fracture

Isolated or in combination with midface fractures

Type 2;

Frontal sinus - posterior wall fracture without dura defect

Isolated or in combination with anterior wall fracture and other midface fractures

Type 3;

Frontal sinus - posterior wall fracture with dura defect Isolated or in combination with anterior wall fractures and other midface fractures

(fig.1).

\section{Diagnosis}

It has become routine practice for patients presenting with severe facial trauma to undergo a computed tomography (CT) scan of the face, head, and neck. Because of the high-energy mechanisms associated with frontal sinus fractures, it is not 
uncommon to see concomitant intracranial injuries and cervical spine injuries; therefore, the neurosurgical service is usually involved in the patient's care. ${ }^{7}$

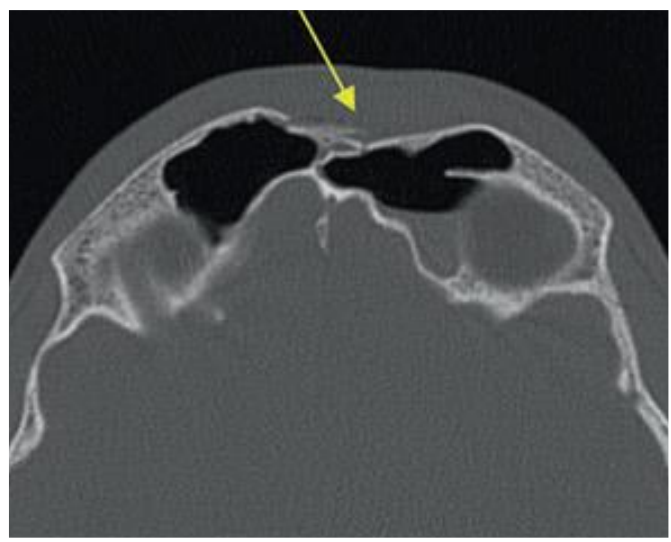

Figure 1. Impression fracture of the anterior frontal sinus wall (arrow). ${ }^{2}$

Computed tomography is commonly used to evaluate patients with blunt facial trauma. With the high definition of the current scanners, even small fractures of the facial skeleton can be visualized. In complex midface injuries, it can be difficult for the radiologist to know which fractures are important to point out to the surgeon. An understanding of the anatomically relevant and surgically accessible craniofacial buttresses is critical for management of these injuries. ${ }^{4}$ Clinical examination along with conventional radiography have been playing a major role in the diagnosis and treatment planning of maxillofacial injuries. Superimposition of bony structures and hindered visualization of underlying fractures by soft tissue swelling and hemorrhage, however, may necessitate further investigation. ${ }^{8}$

System has been developed that can produce three dimensional images from routine CT data. Images can be rotated and split and anatomic structures can be separated and individual images of different tissues types can be generated. 3D images provide an overall spatial concept that allows better understanding of the complexity on multiple $2 \mathrm{D}$ axial CT imaging. With 3D CT we are able to focus on specific areas of clinical and surgical concern. We can easily appreciate the post operative repair and the postoperative complications that may occur. 3D reconstruction is useful in visualizing bone fragments from all angles and planes. Not only the extent of fracture fragments but a suggestion of the mechanism of the injury can be readily assessed. Moreover, 3D CT reformations have helped a lot in patient and family education (Fig.2). ${ }^{8}$

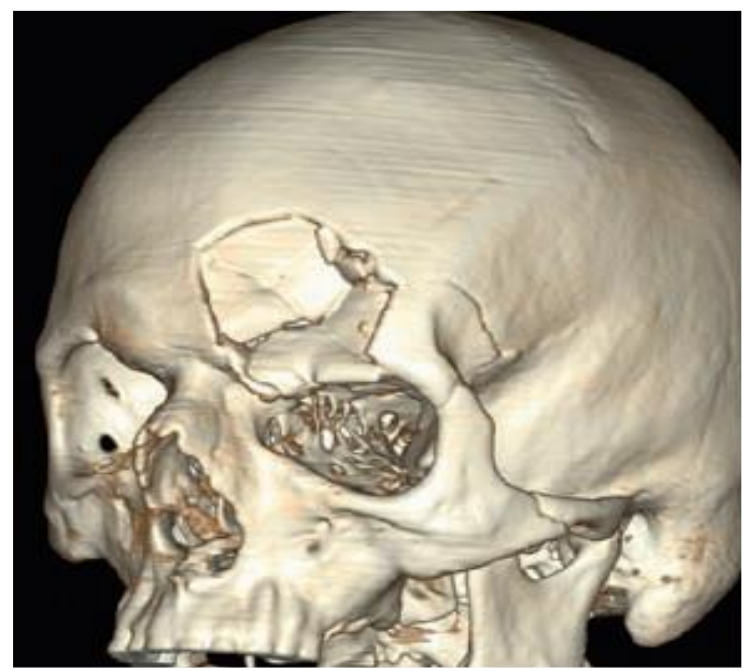

Figure 2. Frontal impression fracture with contusion injury to left frontal lobe. ${ }^{2}$

The compact structure of the NFR makes accurate diagnosis of isolated NFR fractures difficult. A thorough physical examination with nasal endoscopy should be done and a thin-cut CT scan obtained. Fractures involving the floor of the FS or the anterior ethmoid region should raise suspicion for NFR injury. ${ }^{1}$ The treatment of a patient with a nasofrontoorbital injury is a multidisciplinary procedure that involves the plastic surgery, neurosurgery, ophthalmology, and maxillofacial surgery disciplines. This combined approach ensures that the correct diagnosis is made, thus avoiding future problems. ${ }^{10}$ Treatment options include reconstruction of the drainage system, obliteration of the sinus or observation with medical management. Prolonged stenting of the outflow tract has been advocated by Luce, but is associated with stenosis and is considered by many to have an unacceptable failure rate $(30 \%)$. Alternatively, the Sewall-Boyden reconstruction may be attempted, which involves enlarging the nasofrontal outflow tract and relining the tract with a septal mucoperiosteal flap. Most authors recommend obliteration of the sinus when injury to the nasofrontal outflow tract is suspected because this has traditionally been considered the safer long-term option. ${ }^{12}$ 


\section{Management}

Acute concerns include protection of intracranial structures, identification of associated injuries and control of cerebrospinal fluid (CSF) leakage. The aesthetic forehead contour is also an important consideration in repair. Past surgical modalities that removed the anterior bony frontal surface left life-long disfiguring defects and have been largely replaced by techniques that leave a smooth contour without visible scars. ${ }^{5}$

The management goals for FS fractures include (in decreasing order of importance): protection of intracranial contents, prevention of early and late complications, restoration of aesthetic forehead contour, and return of normal FS function. Accomplishing all of these goals is not always possible. However, reconstruction of a "safe" sinus is imperative. ${ }^{1}$

There are several indications for surgical intervention with frontal sinus trauma. The first, and the most obvious, is severe displacement of the anterior table. The potential for postoperative contour deformities warrants reduction and stabilization of these fracture fragments. ${ }^{7}$

Posterior table involvement is perhaps more controversial. Occasionally, one will see relatively mild anterior table involvement with more displacement of the posterior table. The concern with displacement is twofold. First, displaced posterior table fragments may cause a cerebrospinal fluid (CSF) leak through a tear in the dura. One may be able to detect this on physical exam by seeing fluid leaking from the nose. Many patients, do not have this and instead simply have a postnasal drip. If confirmation is needed, a CT myelogram is helpful in localizing the leak. The other concern regarding posterior table displacement is entrapment of mucosa within the intracranial space. Trapped mucosa here can lead to mucoceles and cause serious complications. ${ }^{7}$

After this has been accomplished, the aesthetic and functional repair can be addressed. Specific treatment options include observation, open reduction and internal fixation, sinus obliteration, sinus exenteration (Riedel procedure), and sinus cranialization. ${ }^{1}$ Observational treatment was indicated in nondisplaced stable fractures and general condition of the patient not allowing for surgical intervention. Ideally, any displaced fracture should be treated by open reduction and internal fixation. The number of approaches depend on the extent of dislocation, comminution and the degree of stability following reduction based on clinical evaluation and $\mathrm{CT}$ scan findings. ${ }^{9}$

\section{CASE REPORT}

A 28-year-old man presented to ORL-HNS outpatient clinic Dr. M. Djamil Hospital on August 28th 2017 for post sutured at the left ear controlled after having an accident 2 weeks before, the patient has been inward in surgery department with diagnosis head injury GCS 15 and open fracture right frontal region with anterior frontal wall ruptured and posterior frontal wall intact and right maxillary fracture

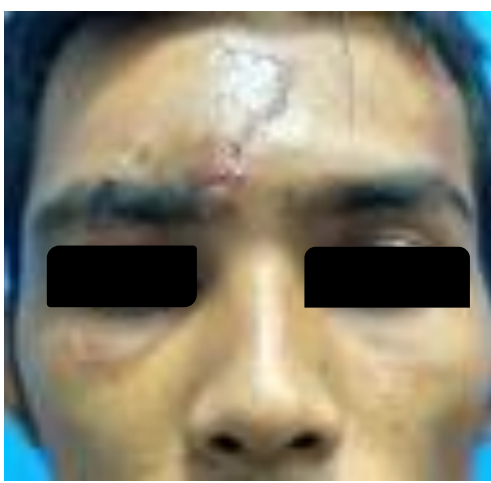

Figure 3. Picture of the patient before the operation

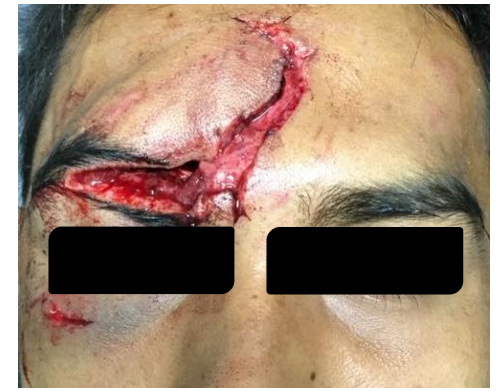

Figure 4. Picture of the patient after the accident

Previously the patient was riding a motorcycle with his relatives, suddenly the motorcycle got slipped and had crashed. The patient was unconscious after the incident, no vomiting after the accident, no seizures after the incident, there was laceration on the right forehead, and no blood came out from the nose, ears 
and mouth. The patient being consulted to the ORLHNS department for laceration on the left ear, and being inward in surgery department after joint operation with ORL-HNS department wound exploration and debridement at the frontal region and laceration at the left ear in the operating room

Two weeks later the patient had controls to the ORL-HNS department to control the wound on the left ear and complains that there was tenderness in wound on the right forehead and no surgery has been performed to reconstruct the fracture at his right forehead. From the physical examination revealed the general condition was moderately ill with the Glasgow Coma Scale (GCS) 15. There was no abnormality on ear and nose examination, there was laceration that already sutured at his right forehead and right frontal fractures at his frontal region, there was no crepitation, and tenderness. There was no abnormality in intranasal examination, no cerebrospinal fluid rhinorrhea.

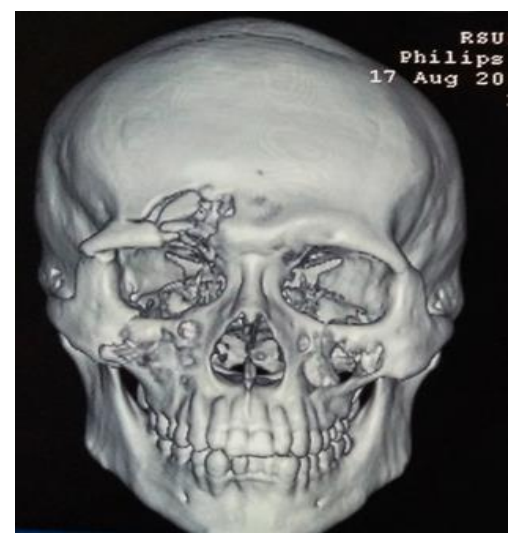

Figure 5. 3D CT scan of the patient

$$
\text { Intraoral examination revealed no }
$$
abnormality, Facial examination revealed no midfacial edema and no tenderness on palpation. In the right orbita region revealed no abnormality, no abnormality in left orbita, palpebra, no hematoma, eye ball movement was free, no tenderness when moving the eyeball.

Intraoral examination revealed, abnormality, Facial examination revealed no midfacial edema and no tenderness on palpation. In the right orbita region revealed no abnormality, no abnormality in left orbita, palpebra, no hematoma, eye ball movement was free, no tenderness when moving the eyeball.

Computed tomography (CT) scanning with three-dimensional (3D) reconstructions of face examination showed multiple fracture lines on right frontal region, and right maxillary bone (Fig. 5). Laboratory examination revealed in normal limit (haemoglobin 14,2 g/dL, leukocytes 7220/mm3, thrombocytes $406.000 / \mathrm{mm} 3$, haematocrit 43\%, prothrombin time 10,5 seconds, activated partial thromboplastin time, 30.7 seconds.

From ENT department patients were diagnosed with multiple maxillofacial fracture (right frontal fracture + right maxilla fracture, patients were inward for reconstruction with open reduction internal fixation (ORIF) using mesh on the frontal region and given IVFD RL 8 hours / kolf, 1 gram of ceftriaxone injection 1 hour before the operation, and the operation was performed on september $6^{\text {th }} 2017$ 09:00 a.m.

\section{Operation report :}

1. The patient lying on operation table under general anesthetic

2. Performed aseptic and antiseptic in the operation area.

3. Performed incision at sutured wound laceration at the right frontal region until we can see the frontal sinus exposed and found that there was missing bone from the right anterior frontal sinus.

4. Evaluation performed to find the missing bone.

5. The wound was extended to the edge of the bone

6. Drilling on the frontal bone for plate and screw installation at rim orbita region, and drilling on the frontal bone for mesh $1,2 \mathrm{~mm}$ and screw $1,2 \mathrm{~mm}$ installation

7. Perform reconstruction of frontal bone and fixated with mesh and screw.

8. Performed Sutured layer by layer using chromic 4.0 and prolene 6.0

9. Apply chloramphenicol zalf to the wound that already been sutured

10. The operation finished. 


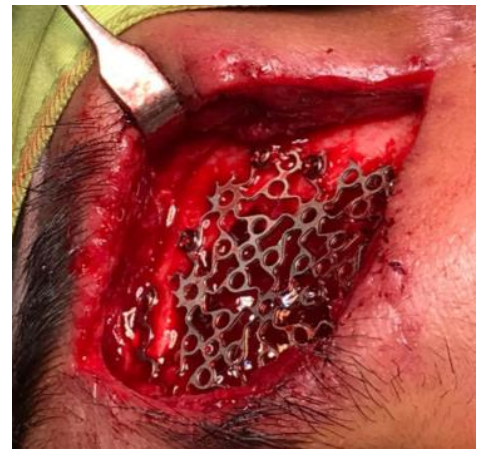

Figure 6. Picture of the patient during the operation

From post operative, there was minimal pain at the right frontal region, no blood came out from the wound, no edema and the patient was diagnosed with post frontal bone reconstruction and open reduction with internal fixation using mesh and screws on the right frontal bone as indication of right frontal fracture and given therapy with IVFD RL inf + tramadol inj drip $100 \mathrm{mg} 8$ hours / kolf, ceftriaxone inj $1 \mathrm{gr} 2$ daily iv, injection of dexamethasone $5 \mathrm{mg} 3$ times daily iv.

On the next two days, from evaluation found no active bleeding and no tenderness and no sign of infection and given therapy with $3 \times 150 \mathrm{mg}$ clindamicyn tablets, mefenamic acid tablets $500 \mathrm{mg} 3$ times daily and chloramphenicol eye zalf 3 times daily for the post operative wound and the patient can go home.

Patient came at September $11^{\text {th }} 2017$ for post operative control, there was minimal in tenderness, no sign of infection, no edema, no pus, and diagnosed with post right frontal bone reconstruction and open reduction with internal fixation using using mesh and screws on the right frontal bone. The sutured on the wound are partially removed and given therapy $3 \times 150$ mg clindamicyn tablets, mefenamic acid tablets 500 mg 3 times daily and chloramphenicol eye zalf 3 times daily.

Patient came again at ORL-HNS outpatient clinic at september $14^{\text {th }} 2017$ for the $2^{\text {nd }}$ post operative control, there was no tenderness, no sign of infection, no edema, no pus, and diagnosed with post right frontal bone reconstruction and open reduction with internal fixation using using mesh and screws on the right frontal bone. The sutured on the wound are removed completely and given therapy $3 \times 150 \mathrm{mg}$ clindamicyn tablets, mefenamic acid tablets $500 \mathrm{mg} 3$ times daily and chloramphenicol eye zalf 3 times/d.

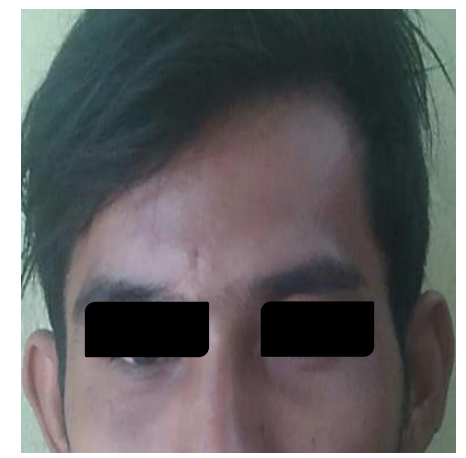

Figure 7. Picture of the patient after 1,5 year post operation

Three weeks after the operation, the patient controlled to ENT-HNS outpatient clinic. No sign of infection, no complained of rhinorrhea, pain and numbness on the right frontal region and right cheek by the patient. Patients was diagnosed with post right frontal bone reconstruction and open reduction with internal fixation using using mesh and screws on the right frontal bone as indication of right frontal fracture and did not given any therapy.

\section{DISCUSSION}

A case of a right fontal sinus fracture was reported in a 28-year-old man. Maxillofacial injuries remain a challenge for oral and maxillo-facial surgeons, demanding both skill and a high level of expertise. The midfacial fractures (maxilla and zygoma) is a part of all skull fractures and their prevalence differs depending on the country, ranging from $17 \%$ in Brazil, to $26 \%$ in Austria and up to $60 \%$ in Turkey. These differences might be due to the socioeconomic, cultural and environmental factors related to changes in the trauma pattern. ${ }^{11}$

The FS is protected by thick cortical bone and is more resistant to fracture than any other facial bone. ${ }^{1}$ FS fractures account for only 5 to $15 \%$ of maxillofacial injuries and are most commonly associated with motor vehicle accidents, sporting events, and assaults. ${ }^{7}$ Usually, the trauma is caused by high-velocity impact; therefore, approximately $75 \%$ of the cases have associated orbital, nasal, and/or other midfacial fractures, The extent of sinus pneumatization, direction of impact, and collision force infl uence the degree of injury. Nahum as quoted by Winkler reported the force required to fracture the frontal sinus to be $800-1600 \mathrm{lb}$, which is significantly 
higher than that of any other area of the skull. The forces required to produce frontal sinus fractures will often cause multiple craniofacial injuries. Posterior table fractures indicate severe injury and result in pneumocephalus in $25 \%$ of patients, CSF leak in $25 \%$ and extradural hematoma in $10 \% .^{12}$

Cannell et al as quoted by Pappachan surveyed head and facial injuries after low speed motor vehicle accidents. They found that the direct impact of the rider against an object is the most obvious cause of subsequent head injury after accidents. Frontal impact accidents tend to produce direct damage to the area of the head or face impacted against the object. In addition, the sudden deceleration, if great enough, would tend to produce intra-cranial damage by the contre-coup mechanism. ${ }^{13}$

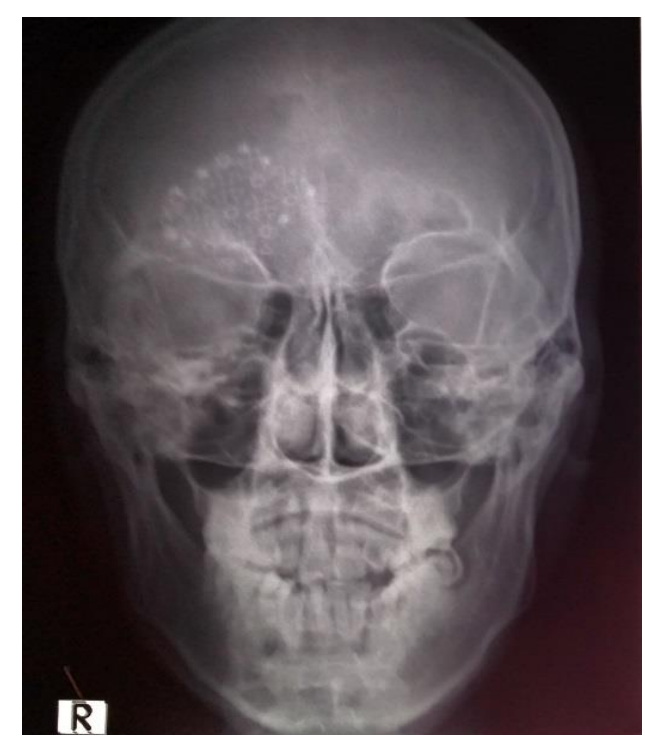

Figure 7. Post operative X-ray

All patients require a through physical examination and radiologic workup, with particular attention given to the frontonasal duct and associated fractures. ${ }^{10}$ Computed tomography is commonly used to evaluate patients with blunt facial trauma. With the high definition of the current scanners, even small fractures of the facial skeleton can be visualized. In complex midface injuries, it can be difficult for the radiologist to know which fractures are important to point out to the surgeon. An understanding of the anatomically relevant and surgically accessible craniofacial buttresses is critical for management of these injuries. ${ }^{4}$ The hallmark of frontal sinus fracture is frontal depression, often accompanied by forehead lacerations. A neurosurgical consultation is necessary if there is any concern for intracranial injury or suspicion of CSF leak. Often periorbital ecchymosis and edema is present. Abnormal vision or extraocular movement restriction warrants an ophthalmologic evaluation. ${ }^{12}$

The treatment strategy should be individualized according to the extent of the injury. Inappropriate initial treatment of frontal sinus fractures may lead to both early and late serious complications, such as mucopyocele, meningitis, and brain abscess. ${ }^{10}$ In this patient we found that patient has been inward in surgery department with diagnosis head injury GCS 15 and open fracture right frontal region with anterior frontal wall ruptured and posterior frontal wall intact and right maxillary fracture, and we found a lacerations at right forehead that already been sutured, no edema, no sign of infection from the post-operative wound, the patient came to ORL-HNS outpatient clinic for control post sutured at left ear from the same accident and complaint felt pain from post sutured laceration at his right forehead. The patient already had operation before in surgery department for exploration and debridement from his laceration and right frontal fracture but it did not doing any reconstructive operation and scheduled for the reconstructive operation for the next 1 month. The patient told us want to take operation immediately and we performed the operation 1 week later.

The main goals in the treatment of frontal sinus fractures are (1) protection of intracranial structures and control of CSF leakage, (2) prevention of late complications and (3) correction of aesthetic deformity. Robiony et al in his study says the goal of frontal sinus fracture management is to create a safe sinus, restore facial contour, and avoid short-term and long-term complications. ${ }^{14}$ The best surgical approaches are coronal and hemicoronal, although fractures can also be approached through an existing forehead laceration. If wider access is required, an existing laceration can be extended to improve the surgical field of view and access. 
Frontal sinus fractures can be classified into fractures of the anterior table or the posterior table with or without associated nasofrontal outflow tract injury ${ }^{12}$ :

\section{Anterior table fracture}

a.With or without displacement

b.With or without outflow tract injury

\section{Posterior table fracture}
a.With or without displacement
b.With or without dural injury/CSF leak
c. With or without outflow tract injury

Displacement is defined as greater than one table width. Posterior table fractures commonly occur in with anterior table fractures, and frequently associated with dural or intracranial injury. Management of CSF leaks and dural tears will often dictate acute treatment. Surgical intervention of highrisk region must provide a "safe" sinus that will resist future infectious complications. ${ }^{12}$

In preoperative, the surgical team needs to have a thorough understanding of the degree and nature of damage to the facial buttresses in order to plan their exposure and restore them accurately. With the high definition of CT, even minor, clinically irrelevant fractures of the facial skeleton can be visualized. In complex midface injuries with multiple fractures, it is important to distinguish those that have direct surgical relevance. ${ }^{15}$ System has been developed that can produce three dimensional images from routine CT data. Images can be rotated and split and anatomic structures can be separated and individual images of different tissues types can be generated. 3D images provide an overall spatial concept that allows better understanding of the complexity on multiple $2 \mathrm{D}$ axial $\mathrm{CT}$ imaging. With $3 \mathrm{D}$ CT we are able to focus on specific areas of clinical and surgical concern. We can easily appreciate the postoperative repair and the postoperative complications that may occur. ${ }^{8} 3 \mathrm{D}$ reconstruction is useful in visualizing bone fragments from all angles and planes. Not only the extent of fracture fragments but a suggestion of the mechanism of the injury can be readily assessed. ${ }^{14}$ In this case the patient already performed brain CT scan with $3 \mathrm{D}$ reconstruction, that we use for visualizing the bone fragment for the suspicious maxillofacial fracture and can be useful for guiding the reconstructive operation for the patient. We found there was fracture at the right frontal region and fracture the right maxilla.

Open reduction is important to restore the bone fragment to their approximate premorbid positions, which can be for the treatment of severely maintained with internal fixation hardware. Bone grafts are occasionally required comminuted fractures that do not allow adequate reduction and fixation. Severe comminution of the anterior table (with or without involvement of nasofrontal recess injury) may make open reduction with the existing bone fragments very challenging. Mucosal disruption can result in a nonfunctional sinus postoperatively. In this unusual situation, sinus obliteration may be required. ${ }^{14}$

The ideal material for plates, mesh, and screws used in fracture management is chemically inert, biocompatible, non allergenic, non carcinogenic, cost effective, sterilizable, easy to handle, and radiopaque. ${ }^{14}$, Badie et al as quote by Robiony described the restoration of dural and bone defects in anterior cranial fossa in particularly delicate situations after removal of cranial base tumors. Sekhar et al as quote by Robiony described a similar technique used when free dural margin is not available to sew. It is thin and easy to contour and stabilize, it maintains its shape and retains all bone fragments, it minimizes delayed complications, and it produces fewer artifacts on CT images than other materials do. ${ }^{14}$ In this case we performed the reconstructive operation under 3D CT Scan guide, we performed open reduction internal fixation and make incision from the post sutured laceration at the frontal region, and from surgical findings it was found that a part of the frontal bone was missing. To cover the missing portion of the frontal bone we used mesh and screw on the open defect, there was no outflow tract injury found and posterior wall of the frontal sinus intact and there is no obstruction from the frontal recess. We performed sutured layer by layer first we sutured chromic 4.0 for the muscle and for the skin we sutured with prolene 6.0. for the right maxilla fracture we did not performed ORIF because its already more than 2 weeks and there was no complaint from the right cheek. 
Though early repair is a key tenet in maxillofacial trauma management, the imminent risk of life-threatening intracranial infections, such as meningitis, encephalitis, and brain abscesses, lends a unique urgency to frontal sinus repair. However, these patients are also some of the most critically ill, with competing intracranial and bodily injury that often delays surgical intervention. How long one may delay operative repair of a fractured frontal sinus in the polytrauma patient is unclear. None of the existing treatment algorithms. ${ }^{16}$

The depressed frontal sinus fractures with a fracture depth of $4 \mathrm{~mm}$ or less seldom showed their contour deformity on the skin. However, if the fracture edges are stepped, they can be palpated, and patients can complain about it. Therefore, the patients should be informed about the palpability of fractures and factors influencing delayed skin contour changes on the fractures. These might include fracture location, fracture shape, patient age, and sex. However, it considered only fracture depth and size as variables because the fracture patterns were difficult to categorize, and the age or sex subgroups were very small. Various surgical approaches have been used to treat anterior wall frontal sinus fractures. If a forehead laceration or scar is present on the fracture, it could allow direct access for fracture reduction and fixation of the anterior wall. ${ }^{17}$ In this case the patient already had 2 weeks delayed after inward in surgery department because of head injury and multiple maxillofacial fracture, but when the patient came to ORL-HNS outward clinic, there was no sign of any infection following of the delayed frontal fracture, but it feel tenderness when it palpable.

\section{CONCLUSION}

Frontal sinus fractures account for only 5 to $15 \%$ of maxillofacial injuries and are most commonly associated with motor vehicle accidents, sporting events, and assaults. The force required to fracture the frontal sinus to be $800-1600 \mathrm{lb}$, which is significantly higher than that of any other area of the skull. It required produce frontal sinus fractures that often cause multiple craniofacial injuries.
The management goals include: protection of intracranial contents, prevention of early and late complications, restoration of aesthetic forehead contour, and return of normal FS function. Open reduction is important to restore the bone fragment to their approximate premorbid positions with internal fixation hardware. Bone grafts are occasionally required for comminuted fractures that do not allow adequate reduction and fixation.

\section{REFERENCE}

1. Strong EB, Sykes MJ. Frontal sinus and nasoorbitoethmoid complex fractures, paper ID. In: Frodel J, Holt G R, Larrabee W F, Nachlas N, Park $\mathrm{S} S$, et al editors. Facial plastic reconstructive surgery. $2^{\text {nd }}$ ed, Maryland: Thieme Medical Pub, 2002.p.747-9.

2. Hardt N, Kuttenberger J. Classification of craniofacial fractures. In: Hardt N, Kuttenberger, Kessler P A, Kothbauer K, Treumann T, editors. Craniofacial trauma, diagnosis and management. Berlin Heidelberg, Springer-Verlag, 2010,p. 42-54.

3. Udeabor SE, Akinbami BO, Yarhere KS, Obiechina AE. Maxillofacial of health Sci, Univ of Port Fractures: etiology, pattern of presentation, and treatment in University of Port Harcourt Teaching Hospital, Port Harcourt, Nigeria. Journl of Dent Surg. 2014:1-5.

4. Hopper RA, Salemy S, Sze RW. Diagnosis of midface fractures with ct: what the surgeon needs to know. RadioGraphics. 2006;26(3):783-93.

5. Mahipathy SRR, Durairaj AR, Sundaramurthy $N$, Jesudasan JS. Frontal bone fractures - a report of three different methods of fixation: a case series. Int Surg J. 2017;4(9):3162-5.

6. Leung RM, Walsh WE, Kern RC. Sinonasal anatomy and physiology. In: Johnson JJ, Rosen CA, editors. Bailey BJ, head and neck surgeryotolaryngology, $2^{\text {nd }}\left(5^{\text {th }}\right.$ ed). Philadelphia: JB Lippincott Company; 2014.p.359-62.

7. Echo A, Troy JS, Hollier LH. Frontal sinus fractures. Semin Plast Surg. 2010,24(4):375-82.

8. Kaur J, Chopra R. Three dimensional CT reconstruction for the evaluation and surgical 
planning of mid face fractures: a 100 case study, J. Maxillofac. Oral Surg. 2010;9(4):323-8.

9. Munilson J. Application of plates and screws in reconstruction of multiple maxillofacial fractures [case report]. Padang: Fakultas kedokteran, Universitas Andalas; 2015 [diakses Desember 2018]. Available at: http://repository.unand.ac.id

10. Yavuzer R, Sari A, Kelly CP, Tuncer S, Latifoglu $\mathrm{O}$, Celebi $\mathrm{C}$, et al. Management of frontal sinus fractures. Proceeding of the $20^{\text {th }}$ Annual Meeting of the European Society of Ophthalmic Plastic and Reconstructive Surgery, 2002 Sept 19-21; Muenster, Germany. Plast Reconstr Surg. 2005.

11. Zaleckas L, Pečiulienè V, Gendvilienè I, Pūrienè A, Rimkuvienè J. Prevalence and etiology of midfacial fractures: a study of 799 cases, Vilnius, Lithuania. Medicina. 2015;6(5):222-7.

12. Winkler AA, Smith TL, Meyer TK, Le TT, Management of Frontal Sinus Fractures. In: Kountakis SE, Onerci TM, editors. Rhinologic and sleep apnea surgical techniques: Springer; 2007, 18.p.149-58.

13. Pappachan B, Alexander M. Biomechanics of cranio-maxillofacial trauma, Chhattisgarh. India J. Maxillofac. Oral Surg. 2012;11(2):224-30.

14. Robiony M, Pietra LD, Bertossi D, Albanese M, Fresku A. A simple method for the repair of frontal sinus fracture: the bone mesh pull-up technique. Craniomaxillofac Trauma Reconst Journl. 2014;7: 79-84.

15. Kim CH, Kim DH, Song SY. Treatment of frontal sinus fracture using bioabsorbable mesh plates, bundang. Journl of Craniofac Surg. 2012;23(2): 549-51.

16. Kim DW, Yoon ES, Lee BI, Dhong ES, Park SH. Fracture depth and delayed contour deformity in frontal sinus anterior wall fracture. The Journl of Craniofac Surg. July 2012;23(4):991-4.

17. Bellamy JL, Molendijk J, Reddy SK, Flores JM, Mundinger GS, Manson PN. Severe infectious complications following frontal sinus fracture: the impact of operative delay and perioperative antibiotic use. Proceeding of the $58^{\text {th }}$ Annual Meeting of the Plastic Surgery Research Council, 2013 May 19-21; Santa Monica, California. PRS Journl. 2013. 